\title{
FORMULASI DAN UJI ORGANOLEPTIK TEH CELUP DAUN KERSEN (Muntingia calabura L.) UNTUK MEMELIHARA KADAR GULA DARAH DAN PENAMBAHAN RIMPANG JAHE (Zingiber officinale) SEBAGAI PENGHANGAT TUBUH
}

\author{
Ulis Tiyani1 ${ }^{*}$ Suharti $^{2}$ Susi Andriani ${ }^{3}$ \\ ${ }^{1}$ Sekolah Tinggi Ilmu Kesehatan Holistik \\ *Korespondensi: Jl. Veteran No.225 Purwakarta Email: ulistiyani133@gmail.com
}

\begin{abstract}
ABSTRAK
Latar Belakang: Diabetes Mellitus (DM) menurut Kemenkes (2014) merupakan penyakit gangguan metabolik yang disebabkan karena kerusakan pankreas sehingga menyebabkan produksi insulin tidak mencukupi bagi tubuh.

Tujuan Penelitian: Penelitian ini bertujuan untuk membuat formulasi dan uji organoleptik teh celup daun kersen (Muntingia calabura L.) untuk memelihara kadar gula darah dan penambahan rimpang jahe (Zingiber officinale) sebagai penghangat tubuh yang mudah dan praktis untuk dikonsumsi oleh masyarakat.

Metode: Metode penelitian yang digunakan yaitu penelitian tindakan (Action Research) menggunakan instrumen penelitian berupa lembar uji organoleptik dan uji kesukaan. Sediaan hdibuat dengan perbandingan komposisi daun kersen: rimpang jahe (2,5:1, 2,5:2, dan 2,5:3).

Hasil: Hasil penelitian menunjukan susut pengeringan daun kersen sebanyak 6,6\% dan rimpang jahe sebanyak $6 \%$ hal ini sesuai dengan syarat simplisia yaitu kadar air kurang dari $10 \%$. Dilihat secara organoleptis sediaan teh celup daun salam dan rimpang jahe stabil selama 3 minggu dengan penyimpanan di suhu kamar dan suhu dingin dengan proporsi formula yang disukai oleh responden yaitu formula 2 dengan komposisi daun kersen sebanyak 2,5 gran dan rimpang jahe sebanyak 2 gram adalah 97,67\%.

Simpulan: Simpulan dari penelitian ini adalah sediaan teh celup yang disukai masyarakat adalah formula kedua yaitu penambahan rimpang jahe sebanyak 2 gram dan sediaan stabil dalam penyimpanan selama 3 minggu di suhu kamar dan suhu dingin.
\end{abstract}

Kata kunci: Teh celup, Daun Kersen (Muntingia calabura L.), Jahe (Zingiber officinale).

\section{ABSTRACT}

Background: DM (Diabetes Mellitus) according to the Ministry of Health (2014) is a metabolic disease caused by damage to the pancreas which causes insufficient insulin production for the body.

Objective: The aim of this study was to formulate and test organoleptic tea bags of cherry leaves (Muntingia calabura L) to maintain blood sugar levels and add ginger (Zingiber officinale) as a body warmer that is easy and practical for consumption by the public.

Method: The research method used is action research (Action Research) using research instruments in the form of organoleptic test sheets and preference tests. Preparations are made with the composition ratio of cherry leaves of ginger root (2.5: 1, 2.5: 2, and 2.5: 3).

Results: The results showed that the drying loss of cherry leaves was 6.6\% and ginger rhizome was 6\%, this is in accordance with the simplicia requirements, namely water content less than 10\%. Organoleptically viewed from the formulation of bay leaf tea bag and ginger rhizome stable for 3 weeks with storage at room temperature and cold temperature with the proportion of the formula favored by the respondent, namely formula 2 with a composition of 2.5 gran kersen leaves and 2 grams of ginger rhizome is $97,67 \%$.

Conclusion: The conclusion of this study is that the tea bag that is preferred by the public is the second formula, namely the addition of 2 grams of ginger rhizome and a stable preparation in storage for 3 weeks at room temperature and cold temperature. 
Keywords: tea bag, cherry leaves (Muntingia calabura L.), ginger (Zingiber officinale).

\section{PENDAHULUAN}

Diabetes Mellitus (DM) merupakan penyakit gangguan metabolik yang disebabkan karena kerusakan pankreas sehingga menyebabkan produksi insulin tidak mencukupi bagi tubuh[10]. Pada penderita DM akan sering merasa lapar hal ini dikarenakan adanya gangguan pada hormon insulin. Fungsi hormon ini salah satunya adalah menurunkan kadar gula dalam darah dengan cara merangsang sel untuk menyerap gula. Ketika hormon ini terganggu, maka kadar gula dalam darah meningkat tanpa adanya penyerapan gula oleh sel, sehingga tidak terjadi glikolisis yang nantinya menjadi ATP untuk energy aktifitas, ini penjelasan untuk lemah/ lemas.

Hasil Riset Kesehatan Dasar (Riskesdas) tahun 2018 menunjukkan bahwa secara nasional, prevalensi DM berdasarkan diagnosis dokter pada rentang usia 55-64 tahun menempati posisi tertinggi sebesar 6,3\%, disusul usia 65-74 tahun sebesar 6,0\%. Prevalensi nasional DM berdasarkan hasil pengukuran kadar gula darah pada penduduk umur $\geq 15$ tahun yang bertempat tinggal di perkotaan adalah $10,6 \%[10]$.

Kersen merupakan tanaman buah tropis yang mudah dijumpai dipinggir jalan. Tanaman ini mempunyai nama yang beragam di beberapa daerah, antara lain kerukup siam (malaysia), jamaican cherry (inggris), talok (jawa), ceri (kalimantan), dan lain-lain. Kersen biasanya ditemui dengan ukuran kecil, pohonnya selalu hijau terus-menerus, berbunga dan berbuah sepanjang tahun [2] Rebusan rebusan daun kersen dengan konsentrasi $15 \%$ efektif menurunkan kadar glukosa darah yang penurunannya sebanding dengan glibenklamid [15].

Jahe (Zingiber officinale) merupakan tanaman rimpang yang termasuk dalam familia zingiberacea. Jahe sangat populer sebagai rempah-rempah, bahan obat, dan banyak dijumpai didaerah pedesaan. Rasa pedas yang terdapat pada jahe memiliki banyak manfaat untuk kesehatan tubuh. Manfaat yang umum digunakan para masyarakat yaitu sebagai obat masuk angin dan mual serta melegakan tenggorokan maupun untuk menghangatkan tubuh.

Keluarga biasanya mengobati kadar gula darah dengan obat sintesis, saya ingin membuat obat herbal untuk mengobati kadar gula darah dari tanaman disekitar rumah yaitu daun kersen yang dibuat dalam sediaan teh celup dengan penambahan rimpang jahe.

Berdasarkan data empiris daun kersen menjadi alternatif sebagai obat herbal, lebih umumnya dikalangan masyarakat sekarang daun kersen di buat dalam bentuk seduhan, penulis tertarik membuat sediaan daun kersen (Muntingia calabura L.) untuk menurunkan kadar gula darah dengan penambahan rimpang jahe sebagai penghangat tubuh dalam bentuk teh celup agar lebih praktis.

Tujuan penelitian ini untuk mengetahui cara pembuatan dan menguji kualitas dengan uji organoleptik sediaan teh celup daun kersen dengan penambahan rimpang jahe terutama untuk memelihara kadar gula darah.

\section{METODE PENELITIAN}

\section{Tempat dan Waktu Penelitian}

Pembuatan Formulasi Teh Celup Daun Kersen (Muntingia calabura L.) Untuk Memelihara Kadar Gula Darah dan Penambahan Rimpang Jahe (Zingiber officinale) Sebagai Penghangat Tubuh di laboratorium Bio medicine yang berlokasi di Jl. Terusan Kapten Halim Km 9 Pondok Salam Purwakarta 41172. Waktu penelitian dilaksanakan minggu ketiga bulan Juli sampai dengan minggu kedua bulan Agustus tahun 2020.

\section{DESAIN PENELITIAN}

Penelitian ini menggunakan desain penelitian tindakan (Action Research) dan menggunakan model penelitian Kurt Lewin yang terdiri dari empat komponen, yaitu perencanaan (planning), tindakan (acting), pengamatan (observing) dan refleksi (reflecting) dimana hubungan yang terjadi 
dari keempat elemen ini dipandang sebagai satu siklus [17].

\section{Prosedur Penelitan \\ Pengumpulan Bahan}

Daun kersen yang digunakan dalam penelitian ini didapatkan dari daerah Kp Sumur Sapi Dua Rt/Rw 001/002 Kecamatan Blanakan Kabupaten Subang. Bagian yang akan digunakan adalah daun yang tua (berwarna hijau tua dan segar) ((Muntingia calabura L.)[18].

Jahe yang digunakan sebagai bahan sediaan pembuatan formulasi teh celup ini diperoleh dari daerah kp Sumur Sapi Dua rt/rw 001/002 kecamatan Blanakan kabupaten Subang. Bagian yang akan digunakan adalah rimpangnya [7].

\section{Alat}

Oven, nampan, kantong teh, kemasan kraft paper, tisu, blender, timbangan digital, sendok plastik, Loyang, pisau.

\section{Bahan}

Daun kersen tua dan segar dan rimpang jahe

\section{Cara Pembuatan Simplisia}

Pada penelitian ini pembuatan simplisia menggunakan metode pengovenan

- Daun kersen segar timbang 100 gram, cuci bersih dengan air mengalir, iris tipis, keringkan menggukanan oven $55^{\circ} \mathrm{C}$ selama 4 jam, blender, jadilah simplisia daun kersen.

- Rimpang jahe segar timbang 50 gram, cuci bersih dengan air mengalir, iris tipis, keringkan menggukanan oven $55^{\circ} \mathrm{C}$ selama 4 jam, blender, jadilah simplisia serbuk rimpang jahe kering

\section{Cara Susut Pengeringan}
a. Timbang masing-masing 5 gram simplisia menggunakan cawan
b. Oven dengan suhu $105^{\circ} \mathrm{C}$ selama 30 menit
c. Masukan kedalam desikator selama 30 menit
d. Timbang dan catat bobot yang di dapat

e. Ulangi proses diatas sampai didapatkan bobot yang sesuai dengan Kriteria Bobot Tetap (KBT) atau hasil konstan.

Untuk menentukan kadar air yang terkandung dalam simplisia, maka digunakan persamaan sebagai berikut:

\%susut pengeringan

$=\frac{(\text { berat cawantsimplisia })-(\text { berat akhir })}{\text { berat simplisia }} \times 100 \%$

\section{Penentuan proporsi formulasi}

Pada penelitian ini proses pembuatan teh celup mengadaptasi (Tuhfa eka,2018) daun kersen dengan jahe

Tabel I. Presentase Formulasi

\begin{tabular}{cccc}
\hline \multirow{2}{*}{ Bahan } & \multicolumn{3}{c}{ Formulasi } \\
& & & \\
Daun kersen & F1 & F2 & F3 \\
& 2,5 gram & 2,5 & 2,5 \\
Rimpang jahe & 1 gram & 2 gram & gram \\
3 gram \\
\hline
\end{tabular}

\section{Parameter yang diamati}

Parameter yang diamati, meliputi uji susut pengeringan, uji organoleptik, dan uji kesukaan.

\section{Uji Organoleptik}

Uji organoleptik merupakan suatu metode pengenalan awal yang sederhana seobjektif mungkin untuk menguji kualitas bahan atau produk. Uji organoleptik dilakukan dengan pengamatan terhadap bentuk, warna, bau, dan rasa[5]. Uji organoleptik dilakukan selama 3 minggu dengan perbandingan komposisi penambahan rimpang jahe, dan perbandingan suhu yaitu suhu ruang dan suhu dingin. Pengujian organoleptik sediaan yaitu mendeskripsikan warna, bau, bentuk, dan rasa pada suatu sediaan. Proses pengamatan dilakukan satu minggu sekali.

\section{Uji kesukaan}

Uji kesukaan merupakan pengujian yang panelisnya mengemukakan respon berupa senang tidaknya terhadap sifat sediaan yang diuji. Uji kesukaan juga disebut uji hedonik. Panelis dimintakan tanggapan pribadinya tentang tingkat kesukaannya. Tingkat- 
tingkat kesukaan ini disebut skala hedonik. Uji kesukaan yang dilakukan terdiri dalam 5 (lima) skala mulai dari sangat tidak suka sampai sangat suka, dengan parameter yang diuji yaitu warna, aroma, dan rasa.

\section{Analisis Data}

Data empirik dikumpulkan melalui hasil data uji organoleprik, dan uji susut pengeringan. Data empirik ini dianalisis secara kualitatif menggunakan naratif dan interpretatif dengan cara mensintesa kedalam sebuah narasi atau cerita dan merajuk kepada teori yang ada.

HASIL PENELITIAN

Susut Pengeringan

Tabel 2 Hasil Susut Pengeringan Simplisia Daun Kersen dan Serbuk Rimpang Jahe

\begin{tabular}{lll}
\hline Data penimbangan & \multicolumn{2}{c}{ Sampel (Gram) } \\
& A & B \\
\hline Berat cawan kosong & $51,77 \mathrm{gr}$ & $52,43 \mathrm{gr}$ \\
Berat cawan + & $56,77 \mathrm{gr}$ & $57,43 \mathrm{gr}$ \\
simplisia & & \\
Berat sampel & $5,00 \mathrm{gr}$ & $5,00 \mathrm{gr}$ \\
Penimbangan 1 & $56,48 \mathrm{gr}$ & $57,17 \mathrm{gr}$ \\
Penimbangan 2 & $56,46 \mathrm{gr}$ & $57,13 \mathrm{gr}$ \\
Penimbangan 3 & $56,44 \mathrm{gr}$ & $57,13 \mathrm{gr}$ \\
$\begin{array}{l}\text { Persentase hasil } \\
\text { susut pengeringan }\end{array}$ & $6,6 \% \mathrm{~g}$ & $6 \%$ \\
\hline
\end{tabular}

Tabel 2 menunjukkan data penimbangan dan susut pengeringan simplisia Daun kersen dan serbuk rimpang jahe, sementara data organoleptis selama 3 minggu dapat dilihat pada Tabel 3 berikut :

\section{Uji Organoleptik}

Tabel 3 Hasil Uji Organoleptik Selama 3 Minggu

\begin{tabular}{|c|c|c|c|c|}
\hline Sampel & Pengamatan & $\begin{array}{l}\text { Minggu ke } \\
-1\end{array}$ & $\begin{array}{c}\text { Minggu ke } \\
-2\end{array}$ & $\begin{array}{c}\text { Minggu ke } \\
-3\end{array}$ \\
\hline & Bau & Sedikit & Sedikit & Sedikit \\
\hline & & khas & khas & khas \\
\hline \multirow{8}{*}{ F1 } & Warna & Hijau & Hijau & Hijau \\
\hline & & tua & tua & tua \\
\hline & Bentuk & Serbuk & Serbuk & Serbuk \\
\hline & & kasar & kasar & kasar \\
\hline & Rasa & Tidak & Tidak & Tidak \\
\hline & & terlalu & terlalu & terlalu \\
\hline & & hangat & hangat & hangat \\
\hline & Bau & $\begin{array}{l}\text { Khas } \\
\text { jahe }\end{array}$ & $\begin{array}{l}\text { Khas } \\
\text { jahe }\end{array}$ & $\begin{array}{l}\text { Khas } \\
\text { jahe }\end{array}$ \\
\hline \multirow[t]{11}{*}{$\mathrm{F} 2$} & Warna & Hijau & Hijau & Hijau \\
\hline & & kekuni & kekuni & kekuni \\
\hline & & & ng- & ng- \\
\hline & & $\begin{array}{l}\text { kuning } \\
\text { an }\end{array}$ & $\begin{array}{l}\text { kuning } \\
\text { an }\end{array}$ & $\begin{array}{l}\text { kuning } \\
\text { an }\end{array}$ \\
\hline & Bentuk & Serbuk & Serbuk & Serbuk \\
\hline & & kasar & kasar & kasar \\
\hline & Rasa & Hangat & Hangat & Hangat \\
\hline & $\mathrm{Bau}$ & Khas & Khas & Khas \\
\hline & & jahe & jahe & jahe \\
\hline & & lebih & lebih & lebih \\
\hline & & pekat & pekat & pekat \\
\hline \multirow[t]{7}{*}{ F3 } & Warna & Hijau & Hijau & Hijau \\
\hline & & kekuni & kekuni & kekuni \\
\hline & & ng- & ng- & ng- \\
\hline & & $\begin{array}{l}\text { kuning } \\
\text { an }\end{array}$ & $\begin{array}{l}\text { kuning } \\
\text { an }\end{array}$ & $\begin{array}{l}\text { kuning } \\
\text { an }\end{array}$ \\
\hline & Bentuk & Serbuk & Serbuk & Serbuk \\
\hline & & kasar & kasar & kasar \\
\hline & Rasa & Hangat & Hangat & Hangat \\
\hline
\end{tabular}

Setelah diuji secara organoleptis, sediaan diujicobakan kepada 20 orang responden, respon yang diberikan terlihat pada Tabel 4 


\section{Tabel 4 Uji Kesukaan}

\begin{tabular}{|c|c|c|c|c|}
\hline \multirow{2}{*}{$\begin{array}{l}\text { Jenis } \\
\text { yang } \\
\text { diuji }\end{array}$} & \multirow[t]{2}{*}{ Respon } & \multicolumn{3}{|c|}{$\begin{array}{c}\text { Kode } \\
\text { sampel }\end{array}$} \\
\hline & & F1(\%) & F2(\%) & F3(\%) \\
\hline \multirow[t]{2}{*}{ Bau } & $\begin{array}{l}\text { Tidak } \\
\text { suka }\end{array}$ & 60,67 & 2,33 & 13,34 \\
\hline & Suka & 39,33 & 97,67 & 86,66 \\
\hline \multirow[t]{2}{*}{ Rasa } & $\begin{array}{l}\text { Tidak } \\
\text { suka }\end{array}$ & 53,49 & 2,33 & 3,33 \\
\hline & Suka & 46,51 & 97,67 & 96,67 \\
\hline \multirow[t]{2}{*}{ Warna } & $\begin{array}{l}\text { Tidak } \\
\text { suka }\end{array}$ & 40 & 0 & 13 \\
\hline & Suka & 60 & 100 & 87 \\
\hline
\end{tabular}

\section{PEMBAHASAN}

Berdasarkan pengamatan pada Tabel 4.1 menunjukan hasil susut pengeringan simplisia daun kersen dan serbuk rimpang jahe dilakukan dengan menggunakan 2 sampel, dimana sampel pertama untuk simplisia daun kersen (A) dan sampel untuk simplisia serbuk rimpang jahe (B), berat dari setiap masing-masing sampel sebanyak 5 gram. Susut pengeringan dengan cara menimbang sampel sebanyak 5 gram kemudian dikeringkan menggunakan oven dengan suhu $105^{\circ} \mathrm{C}$ selama 30 menit, kemudian dimasukan kedalam desikator selama 30 menit lalu timbang. Proses dilakukan sebanyak 3 kali hingga didapatkan berat konstan.

Berdasarkan data diatas susut pengeringan yang diperoleh dari 2 sampel daun kersen (A) dan serbuk rimpang jahe (B) menunjukan hasil persentase yang berbeda yaitu $6,6 \%$ untuk sampel A dan $6 \%$ un tuk sampel $B$. hasil susut pengeringan kedua sampel dinyatakan $\leq 10 \%$. Hasil susut pengeringan tersebut menunjukan bahwa bahan yang digunakan telah memenuhi persyaratan simplisia yang baik yaitu mengandung persentase kadar air $\leq 10 \%$ [13] Susut pengeringan dilakukan dengan tujuan menghentikan reaksi enzimatik yang dapat merusak simplisia tersebut [19].

Berdasarkan hasil pengamatan yang tertera pada Tabel 4.2 menunjukan hasil uji organoleptik sediaan teh celup dari daun kersen (Muntingia Calabura L) dan rimpang jahe (Zingiber officinale) yang telah diuji dan diamati selama 3 minggu, pengamatan dilakukan setiap 1 minggu sekali. Pengamatan uji organoleptik meliputi bau, warna, bentuk dan rasa. Data tersebut merupakan hasil formulasi teh celup dengan metode pengovenan yang dilakukan selama 4 jam dengan suhu $55^{\circ} \mathrm{C}$. pengamatan uji organoleptik dengan formulasi yang berbeda dalam suhu kamar dan suhu dingin.

Berdasarkan hasil pengamatan yang tertera pada tabel 4.2 menunjukan hasil uji kesukaan 20 responden terhadap sediaan teh celup dari daun kersen (Muntingia calabura L) dan jahe (Zingiber officinale). Tuhfa eka (2018\}menyatakan dosis daun kersen 2 gram dan 3 gram mampu menurunkan kadar gula darah, oleh karena itu peneliti menentukan dosis daun kersen sebanyak 2,5 gram yang di ambil dari rentang 2-3 gram. Penentuan dosisi yang efektif juga dilakukan dengan membuat formulasi jahe sebanyak 1 gram sebagai dosis awal sebagai penghangat tubuh dengan variasi pada formula 2 sebanyak 2 gram dan 3 gram pada formula 3 . Formula 1 dengan komposisi daun kersen sebanyak 2,5 gram dan jahe sebanyak 1 gram setelah diseduh menghasilkan aroma daun kersen dan sedikit aroma jahe, rasa yang tidak terlalu hangat dan warna yang tidak pekat. Formula 2 dengan komposisi daun kersen sebanyak 2,5 gram dan jahe sebanyak 2 gram setelah diseduh menghasilkan aroma daun kersen dan aroma jahe, rasa yang hangat dan warna sedikit pekat sedangkan formula 3 dengan komposisi daun kersen 2,5 gram dan jahe sebanyak 3 gram setelah diseduh menghasilkan aroma sedikit daun kersen dan aroma jahe yang lebih pekat, rasa hangat dan warna yang yang pekat. Dari hasil uji kesukaan diperoleh data bahwa dari segi aroma, rasa dan warna yang banyak disukai oleh masyarakat yaitu formula 3 dengan komposisi daun kersen 2,5 gram dan jahe sebanyak 2 gram.hal ini dikarenakan jahe sebanyak 2 gram dapat menutupi rasa pahit yang dihasilkan oleh daun kersen.

\section{KESIMPULAN}

Berdasarkan hasil pengamatan dan analisis data yang dilakukan maka dapat disimpulkan bahwa sediaan teh celup 
dibuat dengan metode pengovenan sediaan teh celup yang dibuat dari daun kersen untuk memelihara kadar gula darah dan rimpang jahe sebagai penghangat tubuh. Hasil susut pengeringan yang diperoleh dari 2 sampel yang menunjukan 6,6\% untuk sampel A (daun kersen) dan 6\% untuk sampel B (serbuk rimpang jahe), kadar air dalam daun kersen dan serbuk rimpang jahe telah memenuhi syarat simplisia yaitu $\leq 10 \%$. Hasil uji organoleptik pada suhu ruang dan suhu dingin yang dilakukan pada masing-masing tiga sampel tersebut tidak menunjukan perubahan yang signifikan. Perbedaan hanya terletak pada aroma daun kersen dan pada rasa hangat dari jahe saja. Perbedaan tersebut dipengaruhi oleh penambahan jahe pada setiap formula dengan jumlah yang berbeda-beda. Hasil uji kesukaan menunjukan bahwa formulasi yang banyak disukai masyarakat yaitu formulasi 2 dengan komposisi daun kersen 2,5 gram dan serbuk rimpang jahe sebanyak 2 gram.

\section{DAFTAR PUSTAKA}

1. Apriani, Shinta., Raksanagara, Ardini S., Mambang Sari, C W (2011). Pengaruh Program Edukasi dengan Metode Kelompok terhadap Perilaku Perawatan Diri Pasien Diabetes Melitus Tipe 2.

2. BinaWati, D. K., dan Amilah, S. 2013. Pengaruh Ekstrak Daun Cherry (Muntingia calabura L.) Bioinsecticides Terhadap Kematian Tanah Cacing (Agrotis ipsilon) dan Ulat Kutu (Spodoptera exiqua) pada Leek Tanaman (Allium fistolum). Wahana, 61 (2): 51-57.

3. Chaturvedula VS dan Prakash I. 2011. Aroma, rasa, warna dan konstituen bioaktif Teh. Jurnal Penelitian Tanaman Obat 5 (11): 2110-2124.

4. Danugroho, E.S. \& Widyaningrum, N.R. (2014). Aktifitas Analgetik Infusa Daun Kersen (Muntingia calabura L.) Jurnal Indonesia Ilmu Kedokteran. Vol. 1. No. 2.

5. Departemen Kesehatan RI, 2000, Parameter Standar Umum Ekstrak Tumbuhan Obat, Cetakan Pertama, 311, 17-19, Dikjen POM, Direktorat
Pengawasan Obat Tradisional.

6. Faridah B, Ponda A, Pertiwi HT. Pengaruh Minuman Jahe Terhadap Penurunan Frekuensi Emesis Gravidarum Pada Ibu Hamil Trimester 1 Di Wilayah Puskesmas Lubuk Buaya Padang. J Ilm Kesehat Ar-Rum Salatiga. 2020;4(1):23-31. 17.

7. Handajani SR, Astuti KEW. Pengaruh Pemberian Ekstrak Jahe Dan Kacang Hijau Terhadap Pengurangan Mual Muntah Pada Ibu Hamil Semester 1 Di Puskesmas Ngawen 2 Wonosari Gunung Kidul. J Keperawatan Glob. 2019;4(2):74-120.

8. Handayani F, Sentat T. 2016. Uji aktivitas ekstrak etanol daun kersen (Muntingia calabura L) terhadap penyembuhan luka bakar pada kulit mencit putih jantan (Mus musculus). Jurnal Ilmiah Ibnu Sina 1(2):131-142.

9. Harymbawa, I. W. A. (2016). Hubungan Sedentary Lifestyle Dengan Kadar Glukosa Darah Pada Orang Dewasa Pekerja Konveksi Di Kelurahan Genuk Ungaran Barat. STIKES Ngudi Waluyo. Artikel.

10. Kementerian Kesehatan RI. Situasi dan Analisis Diabetes. Jakarta: Kementerian Kesehatan RI; 2014.

11. kurniawan, Pitra. 2013. Tabolit Cempaka: ManfaatBerbeda dari Buah dan Daun Kersen, www.tabloidcempaka.com/inde.php/ read/ kesehatan/ detail/ 198/ Manfaat-Berbeda-dari-Daun-Kersen\#. Vh5wTkA2fn4. Diaksestanggal 13 Agustus 2015.

12. Nur. (2016). Dukungan Keluarga Dengan Kepatuhan Pasien Diabetes Melitus Dalam Menjalani Pengobatan Di Blud Rsuza Banda Aceh Dukungan Keluarga Dan Kepatuhan Pasien Diabetes Di Dr. Rumah Sakit Zainoel Abidin Banda Aceh. Idea Nursing Journal, VII (2 ISSN: 2087-2879), 4754.

13. Puspitasari, A. D., \& Wulandari, R. L. (2017). Aktivitas antioksidan, penentuan total fenolik dan kandungan flavonoid ekstrak Muntingia calabura L. Pharmaciana, 147-158. 
14. Riset Kesehatan Dasar (Riskesdas) (2018). Badan Penelitian dan Pengembangan Kesehatan Kementerian RI tahun 2018.

15. Stevani, Hedra. (2017). Efektivitas Rebusan Daun Kersen (Muntingia Callabura L) Terhadap Penurunan Kadar Glukosa Darah Pada Mencit (Mus Musculus).

16. Umami, A. K. (2013). Perbedaan Kadar Gula Darah Sebelum Dan Sesudah Senam Diabetes Pada Pasien Diabetes Mellitus Tipe 2 Di Persadia Rumah Sakit Sari Asih Ciputat. UIN Syarif Hidayatullah Jakarta. Skripsi.

17. Coghlan, D. \&amo; Brannick, T. (2014). Doing Action Research in Your Own Organization. Sage Publications Ltd.

18. Priharjanti, D.2007. ((Muntingia calabura http://florabase.calm.wa.gov.au/brow se/flora.

19. Farmakope Herbal Indonesia Ed. I 2008).

20. Tuhfa Eka Indriana(2018) .Pengaruh Pemberian Seduhan Daun Kelor (Moringa oleifera) dan seduhan daun kersen (Muntingia calabura L) terhadap penurunan kadar glukosa darah pada penederita Diabetes Mellitus di desa Pangarangan, Kecamatan Kota Sumenep, Kabupaten Sumenep. 